\title{
Sistem Pendukung Keputusan Seleksi Penerimaan Calon Siswa/i Baru Menggunakan Algoritma C4.5 (Studi Kasus: SDIT An-Najah Jatinom Klaten)
}

\author{
Oleh: Anief Fauzan Rozi \\ Program Studi Sistem Informasi, Fakultas Teknologi Informasi, Universitas Mercu Buana Yogyakarta \\ Jl. Wates Km. 10 Yogyakarta Telp. (0274) 6498211, 6498212 Fax. (0274) 6498213 \\ email: anief@mercubuana-yogya.ac.id
}

\begin{abstract}
Education is very important and one of the keys of the progress of a country. Basic education or elementary school is the first stage of a long journey for a student in taking his or her education. The more parents has awareness in the importance of an education so the more the parents will enroll their children to study in school. Although the number of schools in a certain place is already considered enough, admission of new students still become a unique phenomenon because number of prospective new students entering school is huge but the admission method still uses manual techniques. Whether using a test or previous level report book, the rank and decision making about the acceptance of the students is still done manually. It can also provide opportunities for certain parties to commit fraud in the admission selection from subjective point of view (outside of the fixed criteria) which makes incorrect calculation and grading so the results are not properly valid.

This research would apply the rules that is formed from the decision trees on admission of new students selection process at SDIT An-Najah Jatinom Klaten. A decision tree consists of a set of rules for dividing a heterogeneous population into smaller parts, and more homogeneous with noticing to the goal variables. C4.5 algorithm is one of the algorithms used to form a decision tree.

The purpose of this research is to apply the rules that are formed from the C4.5 decision tree algorithm in admission of new students selection process. The registration (log) is expected to be more structured through this system so operator can easily and quickly process the calculation and ranking the prospective new student. Service becomes more rapid, accurate, effective, and efficient in terms of time and place because the piled print files (takes place and time) can be concise (stored in the database).

The results shows that the system is able to provide recommendations for the admission process based on the criteria and history that have ever happened. Based on sample data of 100 data among several criterias (religion, age, the average time from the each student' place to the school, parents income per month, number of siblings)is is found that religious criteria have the highest gain value in the calculation of the initial node, ie by 0.367877. Finnaly, this system has been running correctly and can help the school admission committee in the selection of new candidate students.
\end{abstract}

Keywords: Decision Support Systems, Algorithms C.45, Gain.

\section{Pendahuluan}

Pendidikan sangatlah penting dan menjadi salah satu kunci dari kemajuan suatu negara. Pendidikan dasar atau sekolah dasar adalah tahap awal dari perjalanan panjang seorang siswa dalam menempuh masa pendidikannya. Sadar akan pentingnya sebuah pendidikan, maka semakin banyak pula orang tua yang mendaftarkan putra-putrinya untuk bersekolah.

Meskipun jumlah sekolah di suatu daerah maju sudah dinilai cukup, masih saja penerimaan calon siswa/siswi baru menjadi sebuah fenomena tersendiri yang dikarenakan banyaknya calon siswa/siswi baru yang masuk sedangkan model penerimaan sekolah masih menggunakan teknik manual. Baik menggunakan model tes atau berdasar nilai rapor jenjang sebelumnya, tetap saja perangkingan dan pengambilan keputusan diterima atau tidaknya calon siswa/siswi masih dilakukan dengan cara manual.

Teknik seleksi yang manual cenderung memberikan kesempatan untuk melakukan kecurangan-kecurangan salah satunya yang bersifat subjektif, artinya pihak tertentu untuk melakukan kecurangan pada tahap seleksi penerimaan dengan sudut pandang subjektif (di luar kriteria yang telah disepakati). Pada akhirnya dikarenakan proses penghitungan dan perangkingan yang tidak akurat menjadikan hasilnya pun tidak sesuai dengan semestinya.

\section{Tinjauan Pustaka}

Beberapa penelitian terdahulu tentang pengambilan keputusan diantaranya adalah penelitian 
yang dilakukan oleh Novaliendry, (2009), dengan judul aplikasi penggunaan metode promethee dalam sistem pendukung keputusan untuk penentuan media promosi studi kasus: STMIK Indonesia. Penelitian ini bertujuan sebagai alat bantu dalam proses penentuan media promosi yang tepat digunakan dan memiliki nilai manfaat yang lebih dari yang lainnya di Sekolah Tinggi Manajemen Informatika Komputer (STMIK) Indonesia Padang.

Nugroho, Simon Pulung; dkk, (2012), melakukan investigasi model Multi-Stage Multi-Attribute-GroupDecisio-Making (MS-MAGDM). Penelitian ini merupakan kajian baru dalam pembuatan bobot dengan menggunakan TWA (Time-Weighted Averaging) operator untuk memadukan keputusan individu menjadi keputusan kelompok. Selain itu juga menggunakan aturan distribusi untuk menentukan bobot dari kelompok pengambil keputusan ataupun bobot pada setiap stage. Penelitian ini akan memberikan simulasi kasus pemilihan suplier dengan menggunakan beberapa pengambil keputusan. Hasilnya adalah pendekataan model GDSS yang diusulkan mampu memberikan rekomendasi pemilihan supplier berdasarkan kriteria dan histori (stage) yang pernah terjadi.

Rosmirati; dkk, (2013), melakukan penelitian analisa penggunaan metode AHP dan fuzzy AHP pada perangkingan tahanan dalam pembebasan bersyarat. Hasilnya secara umum, penilaian dengan menggunakan metode AHP lebih tinggi dibandingkan metode Fuzzy AHP dimana hasil tertinggi dari metode AHP adalah 8.4593 sementara dengan Fuzzy AHP hasil tertingginya 7.2947. Hasil akhir penilaian ini berupa pengurutan narapida dari yang tertinggi sampai yang terendah dalam pembebasan bersyarat. Pada akhirnya sistem yang dikembangkan dengan metode AHP dan Fuzzy AHP ini telah berjalan dengan benar sehingga sistem ini dapat membantu pihak LAPAS dalam pemilihan dan pengurutan narapidana yang mendapatkan pembebasan bersyarat.

Sunjana, (2010), melakukan penelitian tentang klasifikasi data nasabah sebuah asuransi menggunakan algoritma C4.5 untuk mengetahui lancar atau tidaknya resiko kredit. Pola atau pohon keputusan yang telah terbentuk dapat digunakan untuk memprediksi nasabah yang akan bergabung.

Swastina Liliana, (2013), meneliti tentang penerapan algoritma C4.5 untuk penentuan jurusan mahasiswa. Hasil eksperimen dan evaluasi menunjukan bahwa Algoritma Decision Tree C4.5 akurat diterapkan untuk penentuan kesesuaian jurusan mahasiswa dengan tingkat akurasi 93,31 \% dan akurasi rekomendasi jurusan sebesar $82,64 \%$.

Pada penelitian ini, algoritma C4.5 akan digunakan sebagai pembentuk pohon keputusan yang nantinya akan digunakan untuk proses seleksi penerimaan calon siswa/i baru.

Langkah-langkah secara umum pada algortima C4.5 adalah sebagai berikut. (Kusrini, et al, 2009).

1. Temukan atribut sebagai akar (root).

2. Buat cabang untuk tiap-tiap nilai.
3. Bagi kasus dalam cabang.

4. Ulangi proses (langkah 1,2, dan 3) untuk setiap cabang sampai semua kasus pada cabang memiliki kelas yang sama.

Proses penentuan akar dilakukan dengan mencari nilai gain yang tertinggi diantara beberapa atribut yang ada. Adapun rumus untuk mencari nilai gain dapat dilihat pada gambar 1 .

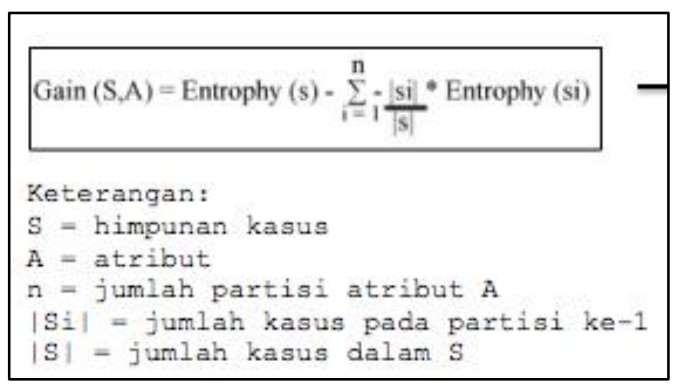

Gambar 1. Rumus Gain

Pada gambar 1 tersebut terdapat nilai entrophy yang dapat dihitung dengan rumus pada gambar 2 .

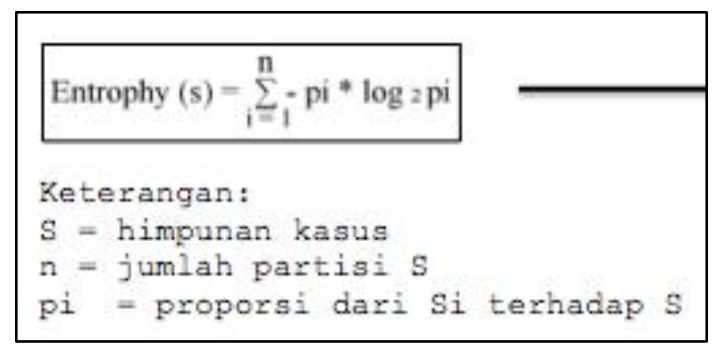

Gambar 2. Rumus Entrophy

\section{Atribut Masukan dan Keluaran}

Atribut yang digunakan sebagai faktor masukan diantaranya adalah usia, rata-rata waktu tempuh dari tempat tinggal ke sekolah, agama, jumlah saudara kandung, dan penghasilan orangtua per bulan.

Sedangkan atribut keluaran atau vatiabel target adalah Hasil Penerimaan.

\section{Data Pelatihan}

Data yang digunakan untuk pelatihan berupa rekapitulasi data penerimaan sebanyak 100 baris data (terlampir pada tabel A).

\section{Proses Pembentukan Pohon Keputusan}

Berikut adalah langkah demi langkah dalam pembentukan pohon keputusan menggunakan algoritma $\mathrm{C} 4.5$.

\subsection{Inisiasi}

Pada perhitungan awal ini diperoleh atribut agama sebagai faktor kunci pertama pada proses penerimaan dengan nilai gain sebesar 0.367877 .

Atribut agama memiliki dua nilai, islam dan nonislam. Pada perhitungan node 1, untuk agama nonislam menghasilkan 0 keputusan diterima dan 33 keputusan tidak diterima. Artinya untuk semua atribut agama yang nilainya non-islam keputusannya adalah tidak diterima, maka anak cabang dari agama nonislam adalah tidak diterima. 
Sedangkan untuk agama Islam, terdapat 44 keputusan diterima dan 23 keputusan tidak diterima. Artinya untuk agama Islam ini belum jelas keputusannya, maka anak cabang dari agama Islam perlu dicari lagi faktor penentu selanjutnya. Adapun perhitungannya dapat dilihat pada gambar 3.

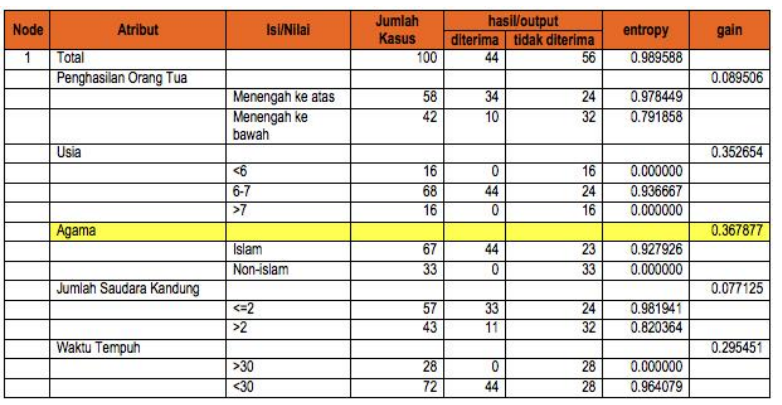

Gambar 3. Perhitungan Pada Node 1

\subsection{Iterasi Pertama}

Pada iterasi pertama ini diperoleh atribut usia sebagai faktor kunci kedua pada proses penerimaan dengan nilai gain sebesar 0.370767 .

Atribut usia memiliki tiga nilai, kurang dari 6 tahun $(<6)$, antara 6-7 tahun (6-7), dan lebih dari 7 tahun $(>7)$. Pada perhitungan node 1.2, untuk umur kurang dari 6 tahun menghasilkan 0 keputusan diterima dan 6 keputusan tidak diterima. Artinya untuk semua atribut usia yang nilainya kurang dari 6 tahun keputusannya adalah tidak diterima, maka anak cabang dari usia kurang dari 6 tahun adalah tidak diterima.

Pada atribut usia dengan nilai lebih dari 7 tahun menghasilkan 0 keputusan diterima dan 7 keputusan tidak diterima. Artinya untuk semua atribut usia yang nilainya lebih dari 7 tahun keputusannya adalah tidak diterima, maka anak cabang dari usia lebih dari 7 tahun adalah tidak diterima.

Sedangkan untuk usia antara 6-7, terdapat 44 keputusan diterima dan 10 keputusan tidak diterima. Artinya untuk usia antara 6-7 tahun ini belum jelas keputusannya, maka anak cabang dari usia antara 6-7 tahun perlu dicari lagi faktor penentu selanjutnya. Adapun perhitungannya dapat dilihat pada gambar 4 .

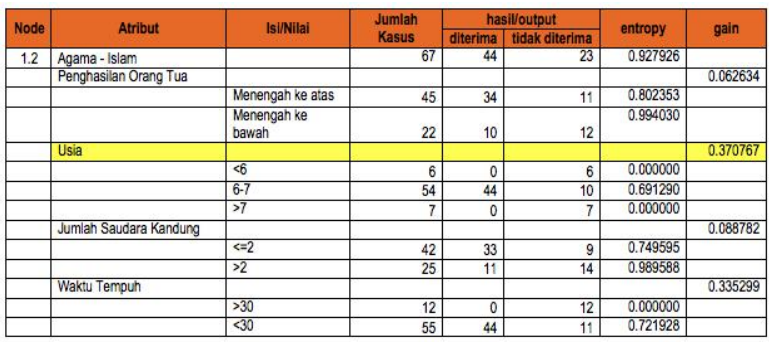

Gambar 4. Perhitungan Pada Node 1.2

\subsection{Iterasi Kedua}

Pada iterasi kedua ini diperoleh atribut waktu tempuh sebagai faktor kunci ketiga pada proses penerimaan dengan nilai gain sebesar 0.323453 . Atribut waktu tempuh memiliki dua nilai, kurang dari 30 menit $(<30)$ dan lebih dari 30 menit (>30). Pada perhitungan node 1.2.2, untuk waktu tempuh lebih dari 30 menit menghasilkan 0 keputusan diterima dan 6 keputusan tidak diterima. Artinya untuk semua atribut waktu tempuh yang nilainya lebih dari 30 menit keputusannya adalah tidak diterima, maka anak cabang dari waktu tempuh lebih dari 30 menit adalah tidak diterima.

Sedangkan untuk waktu tempuh kurang dari 30 menit, terdapat 44 keputusan diterima dan 4 keputusan tidak diterima. Artinya untuk waktu tempuh kurang dari 30 menit ini belum jelas keputusannya dan perlu dicari lagi faktor penentu selanjutnya. Adapun perhitungannya dapat dilihat pada gambar 5 .

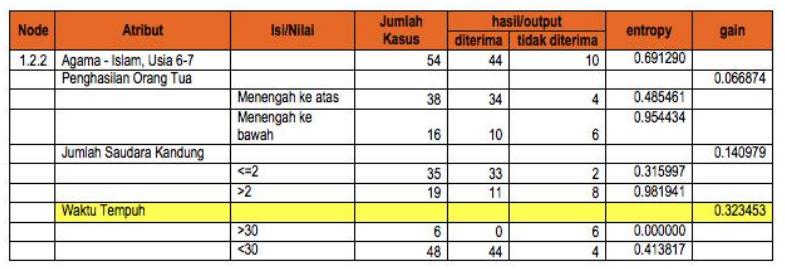

Gambar 5. Perhitungan Pada Node 1.2.2

\subsection{Iterasi Ketiga}

Pada iterasi ketiga ini diperoleh atribut penghasilan orang tua sebagai faktor kunci keempat pada proses penerimaan dengan nilai gain sebesar 0.162073 . Atribut penghasilan orang tua ini memiliki dua nilai, menengah ke atas dan menengah ke bawah. Pada perhitungan node 1.2.2.2, untuk penghasilan menengah ke atas menghasilkan 34 keputusan diterima dan 0 keputusan tidak diterima. Artinya untuk semua atribut penghasilan menengah ke atas keputusannya adalah diterima, maka anak cabang dari penghasilan menengah ke atas adalah diterima.

Sedangkan untuk penghasilan menengah ke bawah terdapat 10 keputusan diterima dan 4 keputusan tidak diterima. Artinya untuk penghasilan menengah ke bawah ini belum jelas keputusannya dan perlu dicari lagi faktor penentu selanjutnya. Adapun perhitungannya dapat dilihat pada gambar 6 .

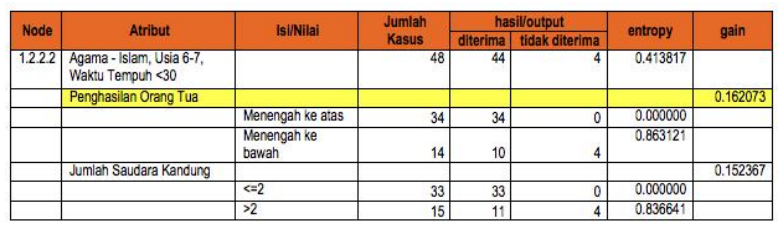

Gambar 6. Perhitungan Pada Node 1.2.2.2

\subsection{Iterasi Keempat/Terakhir}

Pada iterasi keempat ini diperoleh atribut jumlah saudara kandung sebagai faktor kunci kelima sekaligus terakhir pada proses penerimaan dengan nilai gain sebesar 0.863121. Atribut jumlah saudara kandung ini memiliki dua nilai, kurang dari sama dengan dua $(<=2)$ dan lebih dari dua $(>2)$. Pada perhitungan node 1.2.2.2.1, untuk jumlah saudara kandung kurang dari sama dengan dua $(<=2)$ menghasilkan 10 keputusan diterima dan 0 keputusan tidak diterima. Artinya untuk semua atribut jumlah saudara kandung kurang dari sama dengan dua $(<=2)$ keputusannya adalah diterima, maka anak cabang dari jumlah saudara kandung kurang dari sama dengan dua $(<=2)$ adalah diterima. 
Sedangkan untuk jumlah saudara kandung lebih dari dua (>2) menghasilkan 0 keputusan diterima dan 4 keputusan tidak diterima. Artinya untuk semua atribut jumlah saudara kandung lebih dari dua $(>2)$ keputusannya adalah tidak diterima, maka anak cabang dari jumlah saudara kandung lebih dari dua $(>2)$ adalah tidak diterima.

Pada saat ini posisi semua kaki sudah memiliki nilai kelas yang sama. Maka iterasi berhenti dan pohon telah terbentuk dan tahap desain telah selesai. Adapun perhitungannya dapat dilihat pada gambar 7 .

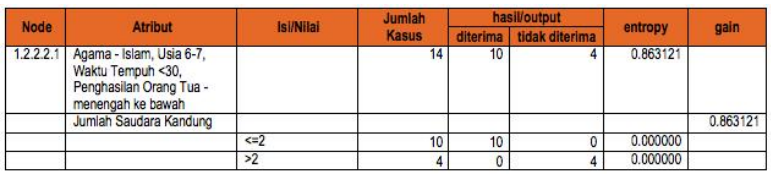

Gambar 7. Perhitungan Pada Node 1.2.2.2.1

\section{Aturan Yang Terbentuk}

Algoritma C4.5 menghasilkan sebuah pohon keputusan yang dapat digunakan untuk membantu dalam pengambilan keputusan. Dalam hal ini pohon keputusan yang dihasilkan dapat dilihat pada gambar 8 .

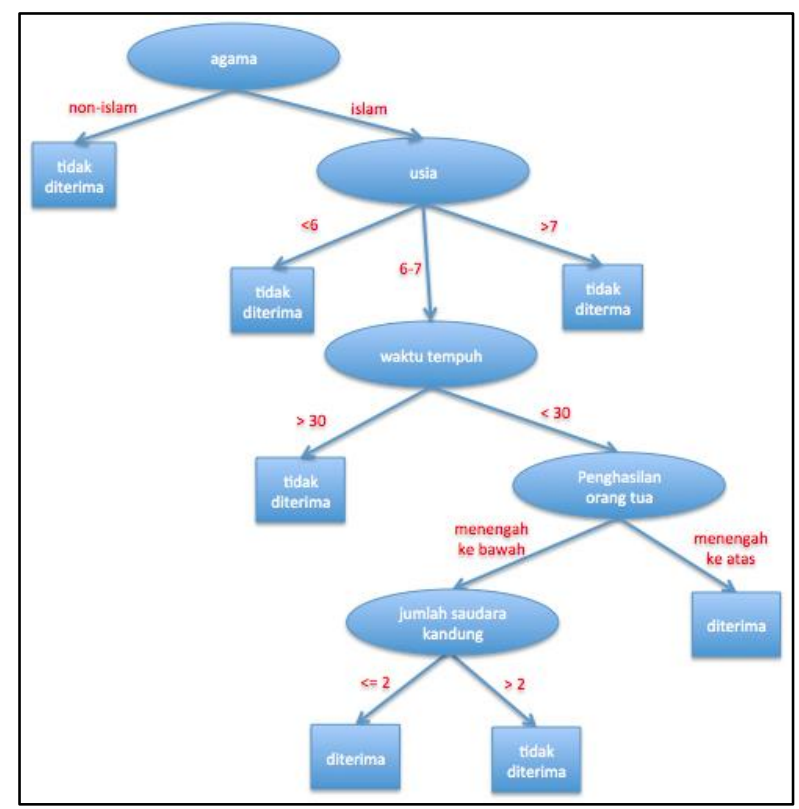

Gambar 8. Pohon Keputusan Seleksi Penerimaan Calon Siswa/i Baru SDIT An-Najah Jatinom Klaten

Berdasar pada pohon keputusan yang terlihat pada gambar 8 tersebut, diperoleh beberapa aturan diantaranya sebagai berikut.

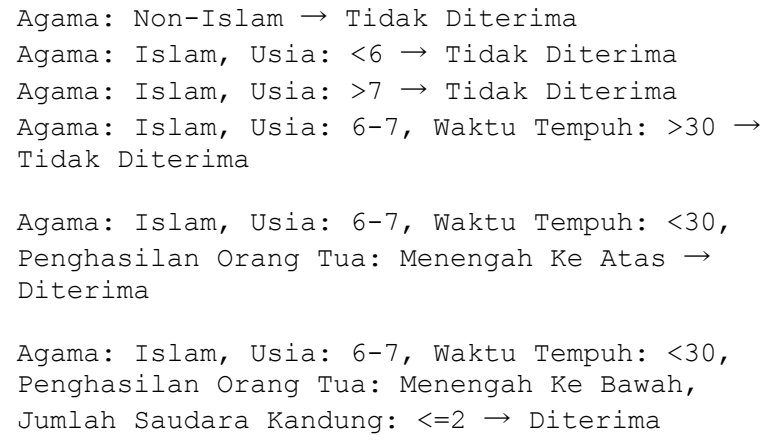

Agama: Islam, Usia: 6-7, Waktu Tempuh: <30, Penghasilan Orang Tua: Menengah Ke Bawah, Jumlah Saudara Kandung: $>2 \rightarrow$ Tidak Diterima

\section{Data Pengujian}

Setelah pohon keputusan terbentuk berdasarkan data pelatihan yang ada, maka berikut adalah data yang diujikan terhadap pohon keputusan tersebut. Data uji sebanyak 100 baris data (terlampir pada tabel B).

Pada 100 baris data tersebut untuk semua yang beragama non-islam hasilnya tidak diterima. Sedangkan yang beragama Islam tetapi usianya kurang dari 6 tahun atau lebih dari 7 tahun juga hasilnya tidak diterima. Bagi yang beragama Islam, usia diantara 6-7 tahun, namun waktu tempuh lebih dari 30 menit juga hasilnya tidak diterima. Sedangkan kurang dari 6 tahun atau lebih dari 7 tahun juga hasilnya tidak diterima. Bagi yang beragama Islam, usia diantara 6-7 tahun, namun waktu tempuh kurang dari 30 menit dan penghasilan orangtua menengan ke atas hasilnya diterima, tetapi bagi yang hasilnya menengah ke bawah dengan jumlah saudara kandung lebih dari 2, maka hasilnya tidak diterima. Sedangkan yang beragama Islam, usia diantara 6-7 tahun, namun waktu tempuh kurang dari 30 menit dan penghasilan orangtua menengan ke bawah dengan jumlah saudara kandung kurang dari sama dengan 2 hasilnya diterima.

\section{Kesimpulan}

Berdasarkan hasil penelitian yang telah dilakukan, dapat disimpulkan beberapa hal sebagai berikut:

1. Proses penghitungan, perangkingan, dan penyeleksian seleksi penerimaan calon siwa/i baru menjadi lebih mudah dan cepat dengan menggunakan sistem pendukung keputusan ini.

2. Proses penghitungan dan perangkingan menjadi lebih akurat, sehingga dapat meminimalisir tindak kejahatan yang dilakukan oleh oknum pada saat proses penerimaan.

3. Pada perhitungan awal ini diperoleh atribut agama sebagai faktor kunci pertama pada proses penerimaan dengan nilai gain sebesar 0.367877 .

4. Pada iterasi pertama diperoleh atribut usia sebagai faktor kunci kedua pada proses penerimaan dengan nilai gain sebesar 0.370767 .

5. Pada iterasi kedua diperoleh atribut waktu tempuh sebagai faktor kunci ketiga pada proses penerimaan dengan nilai gain sebesar 0.323453 .

6. Pada iterasi ketiga diperoleh atribut penghasilan orang tua sebagai faktor kunci keempat pada proses penerimaan dengan nilai gain sebesar 0.162073 .

7. Pada iterasi keempat diperoleh atribut jumlah saudara kandung sebagai faktor kunci kelima sekaligus terakhir pada proses penerimaan dengan nilai gain sebesar 0.863121 .

\section{Daftar Pustaka}

Kusrini dan Emha Taufiq Luthfi. 2009. Algoritma Data Mining. Penerbit Andi Offset, Yogyakarta.

Novaliendry, Dony. 2009. Aplikasi Penggunaan Metode Promethee Dalam Sistem Pendukung 
Keputusan Untuk Penentuan Media Promosi Studi Kasus: STMIK Indonesia. Jurnal Ilmiah KURSOR Vol. 5, No. 2, Juli 2009, hlm.104111.

Nugroho, Simon Pulung; SN, Azhari; Pulungan, Reza. 2012. Pengembangan Model Sistem Pendukung Keputusan Kelompok dengan Metode MultiStage-Multi-Attribute Group Decision Making pada Intelligent Warehouse Management System. The 1st Symposium in Industrial Technology, ISSN: 2302-8033, FTI UPNVY_SINTECH-1.03.008 | C-67 to C-75.

Rosmirati; Sallu, Sulfikar; Suswaini, Eka. 2013. Analisa Penggunaan Metode AHP dan Fuzzy AHP pada Perangkingan Tahanan dalam Pembebasan Bersyarat. Senggarang: Penerbit Fakultas Teknik UMRAH.

Sunjana. 2010. Klasifikasi Data Nasabah Sebuah Asuransi Menggunakan Algoritma C4.5. Seminar Nasional Aplikasi Teknologi Informasi (SNATI). Yogyakarta.

Swastina Liliana. 2013. Penerapan Algoritma C4.5 Untuk Penentuan Jurusan Mahasiswa. STIMIK Indonesia. 


\section{Lampiran}

Tabel A. Rekapitulasi Data Penerimaan Calon Siswa/i Baru SDIT An-Najah Jatinom Klaten

\begin{tabular}{|c|c|c|c|c|c|c|}
\hline No & $\begin{array}{c}\text { Penghasilan Orangtua per } \\
\text { bulan }\end{array}$ & Usia & Agama & $\begin{array}{c}\text { Jumlah Saudara } \\
\text { Kandung }\end{array}$ & $\begin{array}{c}\text { Waktu Tempuh } \\
\text { (menit) }\end{array}$ & Hasil Seleksi \\
\hline 1 & MENENGAH KE BAWAH & $6-7$ & ISLAM & $<=2$ & $<30$ & DITERIMA \\
\hline 2 & MENENGAH KE BAWAH & $6-7$ & NON-ISLAM & $>2$ & $<30$ & TIDAK DITERIMA \\
\hline 3 & MENENGAH KE BAWAH & $6-7$ & ISLAM & $<=2$ & $<30$ & DITERIMA \\
\hline 4 & MENENGAH KE BAWAH & $6-7$ & NON-ISLAM & $>2$ & $<30$ & TIDAK DITERIMA \\
\hline 5 & MENENGAH KE ATAS & $>7$ & NON-ISLAM & $>2$ & $<30$ & TIDAK DITERIMA \\
\hline 6 & MENENGAH KE BAWAH & $6-7$ & ISLAM & $<=2$ & $<30$ & DITERIMA \\
\hline 7 & MENENGAH KE BAWAH & $6-7$ & ISLAM & $<=2$ & $<30$ & DITERIMA \\
\hline 8 & MENENGAH KE BAWAH & $6-7$ & NON-ISLAM & $>2$ & $<30$ & TIDAK DITERIMA \\
\hline 9 & MENENGAH KE BAWAH & $6-7$ & NON-ISLAM & $>2$ & $<30$ & TIDAK DITERIMA \\
\hline 10 & MENENGAH KE BAWAH & $6-7$ & ISLAM & $>2$ & $<30$ & TIDAK DITERIMA \\
\hline 11 & MENENGAH KE ATAS & $>7$ & NON-ISLAM & $<=2$ & $<30$ & TIDAK DITERIMA \\
\hline 12 & MENENGAH KE BAWAH & $>7$ & NON-ISLAM & $<=2$ & $<30$ & TIDAK DITERIMA \\
\hline 13 & MENENGAH KE BAWAH & $6-7$ & ISLAM & $<=2$ & $<30$ & DITERIMA \\
\hline 14 & MENENGAH KE BAWAH & $6-7$ & ISLAM & $<=2$ & $<30$ & DITERIMA \\
\hline 15 & MENENGAH KE BAWAH & $6-7$ & ISLAM & $<=2$ & $<30$ & DITERIMA \\
\hline 16 & MENENGAH KE BAWAH & $6-7$ & ISLAM & $>2$ & $<30$ & TIDAK DITERIMA \\
\hline 17 & MENENGAH KE BAWAH & $6-7$ & ISLAM & $<=2$ & $<30$ & DITERIMA \\
\hline 18 & MENENGAH KE BAWAH & $6-7$ & ISLAM & $<=2$ & $<30$ & DITERIMA \\
\hline 19 & MENENGAH KE ATAS & $6-7$ & ISLAM & $<=2$ & $>30$ & TIDAK DITERIMA \\
\hline 20 & MENENGAH KE ATAS & $>7$ & NON-ISLAM & $<=2$ & $>30$ & TIDAK DITERIMA \\
\hline 21 & MENENGAH KE BAWAH & $6-7$ & ISLAM & $<=2$ & $<30$ & DITERIMA \\
\hline 22 & MENENGAH KE ATAS & $6-7$ & ISLAM & $>2$ & $>30$ & TIDAK DITERIMA \\
\hline 23 & MENENGAH KE ATAS & $6-7$ & ISLAM & $<=2$ & $<30$ & DITERIMA \\
\hline 24 & MENENGAH KE ATAS & $<6$ & ISLAM & $<=2$ & $<30$ & TIDAK DITERIMA \\
\hline 25 & MENENGAH KE ATAS & $6-7$ & ISLAM & $<=2$ & $<30$ & DITERIMA \\
\hline 26 & MENENGAH KE ATAS & $>7$ & NON-ISLAM & $>2$ & $>30$ & TIDAK DITERIMA \\
\hline 27 & MENENGAH KE ATAS & $<6$ & ISLAM & $>2$ & $<30$ & TIDAK DITERIMA \\
\hline 28 & MENENGAH KE BAWAH & $<6$ & ISLAM & $<=2$ & $>30$ & TIDAK DITERIMA \\
\hline 29 & MENENGAH KE BAWAH & $>7$ & ISLAM & $<=2$ & $<30$ & TIDAK DITERIMA \\
\hline 30 & MENENGAH KE ATAS & $6-7$ & ISLAM & $<=2$ & $<30$ & DITERIMA \\
\hline 31 & MENENGAH KE BAWAH & $>7$ & NON-ISLAM & $>2$ & $<30$ & TIDAK DITERIMA \\
\hline 32 & MENENGAH KE BAWAH & $>7$ & ISLAM & $>2$ & $<30$ & TIDAK DITERIMA \\
\hline 33 & MENENGAH KE ATAS & $>7$ & ISLAM & $<=2$ & $>30$ & TIDAK DITERIMA \\
\hline 34 & MENENGAH KE ATAS & $6-7$ & ISLAM & $<=2$ & $<30$ & DITERIMA \\
\hline 35 & MENENGAH KE ATAS & $6-7$ & ISLAM & $<=2$ & $<30$ & DITERIMA \\
\hline 36 & MENENGAH KE ATAS & $>7$ & ISLAM & $>2$ & $>30$ & TIDAK DITERIMA \\
\hline 37 & MENENGAH KE BAWAH & $>7$ & ISLAM & $<=2$ & $>30$ & TIDAK DITERIMA \\
\hline 38 & MENENGAH KE BAWAH & $>7$ & ISLAM & $>2$ & $>30$ & TIDAK DITERIMA \\
\hline 39 & MENENGAH KE BAWAH & $6-7$ & NON-ISLAM & $<=2$ & $<30$ & TIDAK DITERIMA \\
\hline 40 & MENENGAH KE ATAS & $6-7$ & ISLAM & $<=2$ & $<30$ & DITERIMA \\
\hline 41 & MENENGAH KE BAWAH & $6-7$ & NON-ISLAM & $>2$ & $<30$ & TIDAK DITERIMA \\
\hline 42 & MENENGAH KE ATAS & $6-7$ & ISLAM & $<=2$ & $<30$ & DITERIMA \\
\hline 43 & MENENGAH KE ATAS & $6-7$ & NON-ISLAM & $<=2$ & $<30$ & TIDAK DITERIMA \\
\hline
\end{tabular}




\begin{tabular}{|c|c|c|c|c|c|c|}
\hline No & $\begin{array}{c}\text { Penghasilan Orangtua per } \\
\text { bulan }\end{array}$ & Usia & Agama & $\begin{array}{c}\text { Jumlah Saudara } \\
\text { Kandung }\end{array}$ & $\begin{array}{l}\text { Waktu Tempuh } \\
\text { (menit) }\end{array}$ & Hasil Seleksi \\
\hline 44 & MENENGAH KE ATAS & $6-7$ & ISLAM & $<=2$ & $<30$ & DITERIMA \\
\hline 45 & MENENGAH KE ATAS & $6-7$ & NON-ISLAM & $>2$ & $<30$ & TIDAK DITERIMA \\
\hline 46 & MENENGAH KE ATAS & $6-7$ & ISLAM & $<=2$ & $<30$ & DITERIMA \\
\hline 47 & MENENGAH KE BAWAH & $6-7$ & NON-ISLAM & $<=2$ & $>30$ & TIDAK DITERIMA \\
\hline 48 & MENENGAH KE ATAS & $6-7$ & ISLAM & $<=2$ & $<30$ & DITERIMA \\
\hline 49 & MENENGAH KE BAWAH & $6-7$ & NON-ISLAM & $>2$ & $>30$ & TIDAK DITERIMA \\
\hline 50 & MENENGAH KE ATAS & $6-7$ & ISLAM & $<=2$ & $<30$ & DITERIMA \\
\hline 51 & MENENGAH KE ATAS & $6-7$ & NON-ISLAM & $<=2$ & $>30$ & TIDAK DITERIMA \\
\hline 52 & MENENGAH KE ATAS & $6-7$ & NON-ISLAM & $>2$ & $>30$ & TIDAK DITERIMA \\
\hline 53 & MENENGAH KE ATAS & $6-7$ & ISLAM & $<=2$ & $<30$ & DITERIMA \\
\hline 54 & MENENGAH KE ATAS & $6-7$ & ISLAM & $<=2$ & $<30$ & DITERIMA \\
\hline 55 & MENENGAH KE ATAS & $6-7$ & ISLAM & $<=2$ & $<30$ & DITERIMA \\
\hline 56 & MENENGAH KE ATAS & $<6$ & NON-ISLAM & $<=2$ & $<30$ & TIDAK DITERIMA \\
\hline 57 & MENENGAH KE ATAS & $<6$ & NON-ISLAM & $<=2$ & $>30$ & TIDAK DITERIMA \\
\hline 58 & MENENGAH KE ATAS & $6-7$ & ISLAM & $>2$ & $<30$ & DITERIMA \\
\hline 59 & MENENGAH KE ATAS & $6-7$ & ISLAM & $>2$ & $<30$ & DITERIMA \\
\hline 60 & MENENGAH KE BAWAH & $<6$ & NON-ISLAM & $>2$ & $>30$ & TIDAK DITERIMA \\
\hline 61 & MENENGAH KE BAWAH & $>7$ & NON-ISLAM & $>2$ & $>30$ & TIDAK DITERIMA \\
\hline 62 & MENENGAH KE ATAS & $6-7$ & ISLAM & $<=2$ & $<30$ & DITERIMA \\
\hline 63 & MENENGAH KE ATAS & $6-7$ & ISLAM & $<=2$ & $<30$ & DITERIMA \\
\hline 64 & MENENGAH KE BAWAH & $6-7$ & ISLAM & $>2$ & $<30$ & TIDAK DITERIMA \\
\hline 65 & MENENGAH KE BAWAH & $6-7$ & ISLAM & $>2$ & $<30$ & TIDAK DITERIMA \\
\hline 66 & MENENGAH KE ATAS & $6-7$ & ISLAM & $<=2$ & $>30$ & TIDAK DITERIMA \\
\hline 67 & MENENGAH KE ATAS & $6-7$ & ISLAM & $<=2$ & $<30$ & DITERIMA \\
\hline 68 & MENENGAH KE ATAS & $6-7$ & ISLAM & $>2$ & $>30$ & TIDAK DITERIMA \\
\hline 69 & MENENGAH KE BAWAH & $6-7$ & NON-ISLAM & $<=2$ & $>30$ & TIDAK DITERIMA \\
\hline 70 & MENENGAH KE ATAS & $6-7$ & ISLAM & $<=2$ & $<30$ & DITERIMA \\
\hline 71 & MENENGAH KE BAWAH & $6-7$ & NON-ISLAM & $<=2$ & $>30$ & TIDAK DITERIMA \\
\hline 72 & MENENGAH KE BAWAH & $6-7$ & ISLAM & $>2$ & $>30$ & TIDAK DITERIMA \\
\hline 73 & MENENGAH KE BAWAH & $>7$ & NON-ISLAM & $<=2$ & $>30$ & TIDAK DITERIMA \\
\hline 74 & MENENGAH KE BAWAH & $6-7$ & ISLAM & $>2$ & $>30$ & TIDAK DITERIMA \\
\hline 75 & MENENGAH KE ATAS & $6-7$ & ISLAM & $<=2$ & $<30$ & DITERIMA \\
\hline 76 & MENENGAH KE BAWAH & $<6$ & ISLAM & $<=2$ & $<30$ & TIDAK DITERIMA \\
\hline 77 & MENENGAH KE ATAS & $<6$ & ISLAM & $>2$ & $<30$ & TIDAK DITERIMA \\
\hline 78 & MENENGAH KE ATAS & $<6$ & ISLAM & $<=2$ & $>30$ & TIDAK DITERIMA \\
\hline 79 & MENENGAH KE BAWAH & $<6$ & NON-ISLAM & $>2$ & $>30$ & TIDAK DITERIMA \\
\hline 80 & MENENGAH KE ATAS & $6-7$ & ISLAM & $<=2$ & $<30$ & DITERIMA \\
\hline 81 & MENENGAH KE ATAS & $6-7$ & ISLAM & $<=2$ & $<30$ & DITERIMA \\
\hline 82 & MENENGAH KE BAWAH & $<6$ & NON-ISLAM & $>2$ & $>30$ & TIDAK DITERIMA \\
\hline 83 & MENENGAH KE ATAS & $>7$ & NON-ISLAM & $<=2$ & $<30$ & TIDAK DITERIMA \\
\hline 84 & MENENGAH KE ATAS & $>7$ & ISLAM & $>2$ & $<30$ & TIDAK DITERIMA \\
\hline 85 & MENENGAH KE ATAS & $6-7$ & ISLAM & $>2$ & $<30$ & DITERIMA \\
\hline 86 & MENENGAH KE ATAS & $<6$ & NON-ISLAM & $>2$ & $<30$ & TIDAK DITERIMA \\
\hline 87 & MENENGAH KE ATAS & $6-7$ & ISLAM & $>2$ & $<30$ & DITERIMA \\
\hline 88 & MENENGAH KE ATAS & $6-7$ & ISLAM & $>2$ & $<30$ & DITERIMA \\
\hline
\end{tabular}




\begin{tabular}{|c|c|c|c|c|c|c|}
\hline No & $\begin{array}{c}\text { Penghasilan Orangtua per } \\
\text { bulan }\end{array}$ & Usia & Agama & $\begin{array}{c}\text { Jumlah Saudara } \\
\text { Kandung }\end{array}$ & $\begin{array}{c}\text { Waktu Tempuh } \\
\text { (menit) }\end{array}$ & Hasil Seleksi \\
\hline 89 & MENENGAH KE BAWAH & $<6$ & NON-ISLAM & $<=2$ & $<30$ & TIDAK DITERIMA \\
\hline 90 & MENENGAH KE BAWAH & $<6$ & NON-ISLAM & $>2$ & $<30$ & TIDAK DITERIMA \\
\hline 91 & MENENGAH KE ATAS & $6-7$ & ISLAM & $>2$ & $<30$ & DITERIMA \\
\hline 92 & MENENGAH KE ATAS & $6-7$ & ISLAM & $>2$ & $<30$ & DITERIMA \\
\hline 93 & MENENGAH KE ATAS & $<6$ & NON-ISLAM & $>2$ & $>30$ & TIDAK DITERIMA \\
\hline 94 & MENENGAH KE BAWAH & $<6$ & NON-ISLAM & $<=2$ & $>30$ & TIDAK DITERIMA \\
\hline 95 & MENENGAH KE ATAS & $6-7$ & ISLAM & $>2$ & $<30$ & DITERIMA \\
\hline 96 & MENENGAH KE ATAS & $6-7$ & ISLAM & $>2$ & $<30$ & DITERIMA \\
\hline 97 & MENENGAH KE ATAS & $6-7$ & ISLAM & $>2$ & $<30$ & DITERIMA \\
\hline 98 & MENENGAH KE ATAS & $6-7$ & ISLAM & $>2$ & $<30$ & DITERIMA \\
\hline 99 & MENENGAH KE ATAS & $6-7$ & ISLAM & $<=2$ & $<30$ & DITERIMA \\
\hline 100 & MENENGAH KE ATAS & $6-7$ & ISLAM & $<=2$ & $<30$ & DITERIMA \\
\hline
\end{tabular}


Tabel B. Data Uji Sistem Seleksi Penerimaan Calon Siswa/i Baru dengan Algoritma C4.5

\begin{tabular}{|c|c|c|c|c|c|c|}
\hline No & $\begin{array}{l}\text { Penghasilan Orangtua } \\
\text { per bulan }\end{array}$ & Usia & Agama & $\begin{array}{c}\text { Jumlah Saudara } \\
\text { Kandung }\end{array}$ & $\begin{array}{l}\text { Waktu Tempuh } \\
\text { (menit) }\end{array}$ & Hasil Seleksi \\
\hline 1 & MENENGAH KE BAWAH & $6-7$ & NON-ISLAM & $>2$ & $>30$ & TIDAK DITERIMA \\
\hline 2 & MENENGAH KE ATAS & $6-7$ & ISLAM & $<=2$ & $<30$ & DITERIMA \\
\hline 3 & MENENGAH KE BAWAH & $6-7$ & NON-ISLAM & $<=2$ & $>30$ & TIDAK DITERIMA \\
\hline 4 & MENENGAH KE ATAS & $6-7$ & NON-ISLAM & $>2$ & $>30$ & TIDAK DITERIMA \\
\hline 5 & MENENGAH KE ATAS & $6-7$ & NON-ISLAM & $>2$ & $<30$ & TIDAK DITERIMA \\
\hline 6 & MENENGAH KE ATAS & $6-7$ & ISLAM & $<=2$ & $<30$ & DITERIMA \\
\hline 7 & MENENGAH KE ATAS & $6-7$ & NON-ISLAM & $<=2$ & $<30$ & TIDAK DITERIMA \\
\hline 8 & MENENGAH KE ATAS & $<6$ & NON-ISLAM & $<=2$ & $<30$ & TIDAK DITERIMA \\
\hline 9 & MENENGAH KE BAWAH & $6-7$ & NON-ISLAM & $>2$ & $<30$ & TIDAK DITERIMA \\
\hline 10 & MENENGAH KE ATAS & $6-7$ & ISLAM & $>2$ & $<30$ & DITERIMA \\
\hline 11 & MENENGAH KE BAWAH & $6-7$ & NON-ISLAM & $<=2$ & $<30$ & TIDAK DITERIMA \\
\hline 12 & MENENGAH KE BAWAH & $<6$ & NON-ISLAM & $>2$ & $>30$ & TIDAK DITERIMA \\
\hline 13 & MENENGAH KE BAWAH & $>7$ & ISLAM & $<=2$ & $>30$ & TIDAK DITERIMA \\
\hline 14 & MENENGAH KE ATAS & $6-7$ & ISLAM & $<=2$ & $<30$ & DITERIMA \\
\hline 15 & MENENGAH KE ATAS & $6-7$ & ISLAM & $<=2$ & $<30$ & DITERIMA \\
\hline 16 & MENENGAH KE BAWAH & $6-7$ & ISLAM & $>2$ & $<30$ & TIDAK DITERIMA \\
\hline 17 & MENENGAH KE ATAS & $>7$ & ISLAM & $<=2$ & $>30$ & TIDAK DITERIMA \\
\hline 18 & MENENGAH KE ATAS & $6-7$ & ISLAM & $<=2$ & $>30$ & TIDAK DITERIMA \\
\hline 19 & MENENGAH KE BAWAH & $>7$ & NON-ISLAM & $>2$ & $<30$ & TIDAK DITERIMA \\
\hline 20 & MENENGAH KE ATAS & $6-7$ & ISLAM & $>2$ & $>30$ & TIDAK DITERIMA \\
\hline 21 & MENENGAH KE BAWAH & $>7$ & ISLAM & $<=2$ & $<30$ & TIDAK DITERIMA \\
\hline 22 & MENENGAH KE ATAS & $6-7$ & ISLAM & $<=2$ & $<30$ & DITERIMA \\
\hline 23 & MENENGAH KE ATAS & $<6$ & ISLAM & $>2$ & $<30$ & TIDAK DITERIMA \\
\hline 24 & MENENGAH KE BAWAH & $6-7$ & ISLAM & $>2$ & $>30$ & TIDAK DITERIMA \\
\hline 25 & MENENGAH KE ATAS & $6-7$ & ISLAM & $<=2$ & $<30$ & DITERIMA \\
\hline 26 & MENENGAH KE BAWAH & $6-7$ & ISLAM & $>2$ & $>30$ & TIDAK DITERIMA \\
\hline 27 & MENENGAH KE ATAS & $6-7$ & ISLAM & $<=2$ & $<30$ & DITERIMA \\
\hline 28 & MENENGAH KE BAWAH & $<6$ & ISLAM & $<=2$ & $<30$ & TIDAK DITERIMA \\
\hline 29 & MENENGAH KE BAWAH & $6-7$ & ISLAM & $<=2$ & $<30$ & DITERIMA \\
\hline 30 & MENENGAH KE ATAS & $<6$ & ISLAM & $<=2$ & $>30$ & TIDAK DITERIMA \\
\hline 31 & MENENGAH KE ATAS & $6-7$ & ISLAM & $<=2$ & $>30$ & TIDAK DITERIMA \\
\hline 32 & MENENGAH KE ATAS & $6-7$ & ISLAM & $<=2$ & $<30$ & DITERIMA \\
\hline 33 & MENENGAH KE BAWAH & $6-7$ & ISLAM & $<=2$ & $<30$ & DITERIMA \\
\hline 34 & MENENGAH KE BAWAH & $<6$ & NON-ISLAM & $>2$ & $>30$ & TIDAK DITERIMA \\
\hline 35 & MENENGAH KE BAWAH & $6-7$ & ISLAM & $<=2$ & $<30$ & DITERIMA \\
\hline 36 & MENENGAH KE ATAS & $>7$ & ISLAM & $>2$ & $<30$ & TIDAK DITERIMA \\
\hline 37 & MENENGAH KE BAWAH & $6-7$ & ISLAM & $<=2$ & $<30$ & DITERIMA \\
\hline 38 & MENENGAH KE ATAS & $<6$ & NON-ISLAM & $>2$ & $<30$ & TIDAK DITERIMA \\
\hline 39 & MENENGAH KE ATAS & $>7$ & NON-ISLAM & $<=2$ & $<30$ & TIDAK DITERIMA \\
\hline 40 & MENENGAH KE ATAS & $6-7$ & ISLAM & $>2$ & $<30$ & DITERIMA \\
\hline 41 & MENENGAH KE BAWAH & $6-7$ & NON-ISLAM & $>2$ & $<30$ & TIDAK DITERIMA \\
\hline 42 & MENENGAH KE BAWAH & $<6$ & NON-ISLAM & $>2$ & $<30$ & TIDAK DITERIMA \\
\hline 43 & MENENGAH KE BAWAH & $6-7$ & ISLAM & $<=2$ & $<30$ & DITERIMA \\
\hline 44 & MENENGAH KE ATAS & $6-7$ & ISLAM & $>2$ & $<30$ & DITERIMA \\
\hline
\end{tabular}




\begin{tabular}{|c|c|c|c|c|c|c|}
\hline No & $\begin{array}{c}\text { Penghasilan Orangtua } \\
\text { per bulan }\end{array}$ & Usia & Agama & $\begin{array}{c}\text { Jumlah Saudara } \\
\text { Kandung }\end{array}$ & $\begin{array}{c}\text { Waktu Tempuh } \\
\text { (menit) }\end{array}$ & Hasil Seleksi \\
\hline 45 & MENENGAH KE ATAS & $>7$ & NON-ISLAM & $>2$ & $<30$ & TIDAK DITERIMA \\
\hline 46 & MENENGAH KE BAWAH & $<6$ & NON-ISLAM & $<=2$ & $>30$ & TIDAK DITERIMA \\
\hline 47 & MENENGAH KE BAWAH & $6-7$ & ISLAM & $<=2$ & $<30$ & DITERIMA \\
\hline 48 & MENENGAH KE ATAS & $6-7$ & ISLAM & $>2$ & $<30$ & DITERIMA \\
\hline 49 & MENENGAH KE BAWAH & $6-7$ & ISLAM & $<=2$ & $<30$ & DITERIMA \\
\hline 50 & MENENGAH KE ATAS & $6-7$ & ISLAM & $>2$ & $<30$ & DITERIMA \\
\hline 51 & MENENGAH KE ATAS & $6-7$ & NON-ISLAM & $<=2$ & $>30$ & TIDAK DITERIMA \\
\hline 52 & MENENGAH KE ATAS & $6-7$ & ISLAM & $<=2$ & $<30$ & DITERIMA \\
\hline 53 & MENENGAH KE ATAS & $6-7$ & ISLAM & $<=2$ & $<30$ & DITERIMA \\
\hline 54 & MENENGAH KE ATAS & $6-7$ & ISLAM & $<=2$ & $<30$ & DITERIMA \\
\hline 55 & MENENGAH KE ATAS & $6-7$ & ISLAM & $<=2$ & $<30$ & DITERIMA \\
\hline 56 & MENENGAH KE ATAS & $6-7$ & ISLAM & $<=2$ & $<30$ & DITERIMA \\
\hline 57 & MENENGAH KE ATAS & $<6$ & NON-ISLAM & $<=2$ & $>30$ & TIDAK DITERIMA \\
\hline 58 & MENENGAH KE ATAS & $6-7$ & ISLAM & $<=2$ & $<30$ & DITERIMA \\
\hline 59 & MENENGAH KE ATAS & $6-7$ & ISLAM & $>2$ & $<30$ & DITERIMA \\
\hline 60 & MENENGAH KE ATAS & $6-7$ & ISLAM & $<=2$ & $<30$ & DITERIMA \\
\hline 61 & MENENGAH KE BAWAH & $>7$ & NON-ISLAM & $>2$ & $>30$ & TIDAK DITERIMA \\
\hline 62 & MENENGAH KE ATAS & $6-7$ & ISLAM & $<=2$ & $<30$ & DITERIMA \\
\hline 63 & MENENGAH KE ATAS & $6-7$ & ISLAM & $<=2$ & $<30$ & DITERIMA \\
\hline 64 & MENENGAH KE BAWAH & $>7$ & ISLAM & $>2$ & $>30$ & TIDAK DITERIMA \\
\hline 65 & MENENGAH KE BAWAH & $6-7$ & ISLAM & $>2$ & $<30$ & TIDAK DITERIMA \\
\hline 66 & MENENGAH KE ATAS & $>7$ & ISLAM & $>2$ & $>30$ & TIDAK DITERIMA \\
\hline 67 & MENENGAH KE ATAS & $6-7$ & ISLAM & $<=2$ & $<30$ & DITERIMA \\
\hline 68 & MENENGAH KE ATAS & $6-7$ & ISLAM & $<=2$ & $<30$ & DITERIMA \\
\hline 69 & MENENGAH KE BAWAH & $6-7$ & NON-ISLAM & $<=2$ & $>30$ & TIDAK DITERIMA \\
\hline 70 & MENENGAH KE BAWAH & $>7$ & ISLAM & $>2$ & $<30$ & TIDAK DITERIMA \\
\hline 71 & MENENGAH KE BAWAH & $6-7$ & NON-ISLAM & $<=2$ & $>30$ & TIDAK DITERIMA \\
\hline 72 & MENENGAH KE ATAS & $6-7$ & ISLAM & $<=2$ & $<30$ & DITERIMA \\
\hline 73 & MENENGAH KE BAWAH & $>7$ & NON-ISLAM & $<=2$ & $>30$ & TIDAK DITERIMA \\
\hline 74 & MENENGAH KE BAWAH & $<6$ & ISLAM & $<=2$ & $>30$ & TIDAK DITERIMA \\
\hline 75 & MENENGAH KE ATAS & $6-7$ & ISLAM & $<=2$ & $<30$ & DITERIMA \\
\hline 76 & MENENGAH KE ATAS & $>7$ & NON-ISLAM & $>2$ & $>30$ & TIDAK DITERIMA \\
\hline 77 & MENENGAH KE ATAS & $<6$ & ISLAM & $>2$ & $<30$ & TIDAK DITERIMA \\
\hline 78 & MENENGAH KE ATAS & $<6$ & ISLAM & $<=2$ & $<30$ & TIDAK DITERIMA \\
\hline 79 & MENENGAH KE BAWAH & $<6$ & NON-ISLAM & $>2$ & $>30$ & TIDAK DITERIMA \\
\hline 80 & MENENGAH KE ATAS & $6-7$ & ISLAM & $>2$ & $>30$ & TIDAK DITERIMA \\
\hline 81 & MENENGAH KE ATAS & $6-7$ & ISLAM & $<=2$ & $<30$ & DITERIMA \\
\hline 82 & MENENGAH KE ATAS & $>7$ & NON-ISLAM & $<=2$ & $>30$ & TIDAK DITERIMA \\
\hline 83 & MENENGAH KE ATAS & $>7$ & NON-ISLAM & $<=2$ & $<30$ & TIDAK DITERIMA \\
\hline 84 & MENENGAH KE BAWAH & $6-7$ & ISLAM & $<=2$ & $<30$ & DITERIMA \\
\hline 85 & MENENGAH KE ATAS & $6-7$ & ISLAM & $>2$ & $<30$ & DITERIMA \\
\hline 86 & MENENGAH KE BAWAH & $6-7$ & ISLAM & $>2$ & $<30$ & TIDAK DITERIMA \\
\hline 87 & MENENGAH KE ATAS & $6-7$ & ISLAM & $>2$ & $<30$ & DITERIMA \\
\hline 88 & MENENGAH KE BAWAH & $6-7$ & ISLAM & $<=2$ & $<30$ & DITERIMA \\
\hline 89 & MENENGAH KE BAWAH & $<6$ & NON-ISLAM & $<=2$ & $<30$ & TIDAK DITERIMA \\
\hline
\end{tabular}




\begin{tabular}{|c|c|c|c|c|c|c|}
\hline No & $\begin{array}{c}\text { Penghasilan Orangtua } \\
\text { per bulan }\end{array}$ & Usia & Agama & $\begin{array}{c}\text { Jumlah Saudara } \\
\text { Kandung }\end{array}$ & $\begin{array}{c}\text { Waktu Tempuh } \\
\text { (menit) }\end{array}$ & Hasil Seleksi \\
\hline 90 & MENENGAH KE BAWAH & $>7$ & NON-ISLAM & $<=2$ & $<30$ & TIDAK DITERIMA \\
\hline 91 & MENENGAH KE ATAS & $6-7$ & ISLAM & $>2$ & $<30$ & DITERIMA \\
\hline 92 & MENENGAH KE BAWAH & $6-7$ & ISLAM & $>2$ & $<30$ & TIDAK DITERIMA \\
\hline 93 & MENENGAH KE ATAS & $<6$ & NON-ISLAM & $>2$ & $>30$ & TIDAK DITERIMA \\
\hline 94 & MENENGAH KE BAWAH & $6-7$ & NON-ISLAM & $>2$ & $<30$ & TIDAK DITERIMA \\
\hline 95 & MENENGAH KE ATAS & $6-7$ & ISLAM & $>2$ & $<30$ & DITERIMA \\
\hline 96 & MENENGAH KE BAWAH & $6-7$ & ISLAM & $<=2$ & $<30$ & DITERIMA \\
\hline 97 & MENENGAH KE ATAS & $6-7$ & ISLAM & $>2$ & $<30$ & DITERIMA \\
\hline 98 & MENENGAH KE BAWAH & $6-7$ & NON-ISLAM & $>2$ & $<30$ & TIDAK DITERIMA \\
\hline 99 & MENENGAH KE ATAS & $6-7$ & ISLAM & $<=2$ & $<30$ & DITERIMA \\
\hline $\begin{array}{c}10 \\
0\end{array}$ & MENENGAH KE BAWAH & $6-7$ & NON-ISLAM & $>2$ & $<30$ & TIDAK DITERIMA \\
\hline
\end{tabular}

